\title{
A proinflammatory marker in chronic rhinosinusitis: serum calprotectin
}

\author{
Tuba Candar', Deniz Baklaci2 ${ }^{\Xi}$, İhsan Kuzucu ${ }^{3}$ and Serkan Kayabasi ${ }^{4}$ \\ 1 Ufuk University, Department of Biochemistry, Ankara, Turkey; ${ }^{2}$ Bülent Ecevit University, Department of Otolaryngology, Zonguldak, Turkey; \\ ${ }^{3}$ Medisun Private Hospital, Department of Otolaryngology, Ankara, Turkey; ${ }^{4}$ Aksaray University, Department of Otolaryngology, Aksaray, Turkey
}

\begin{abstract}
Introduction: Studies have shown that calprotectin has a strong pro-inflammatory effect. Elevated calprotectin levels in the serum can be used as a strong clinical marker indicating the presence of inflammation. Objective: To investigate serum calprotectin levels in patients with chronic rhinosinusitis (CRS) and to determine the applicability of calprotectin as a potential molecular proinflammatory biomarker for CRS. Methods: The study consisted of three groups: chronic rhinosinusitis with polyps (CRSwNP group), chronic rhinosinusitis without polyps (CRSwoNP), and healthy control. CRS patients with polyps were further divided into two groups depending on the presence/absence of Samter's triad. The Nose Obstruction Symptom Evaluation (NOSE) scale score and serum calprotectin value were evaluated in all participants. Results: The mean serum calprotectin value was $79.5 \pm 11.8 \mathrm{ng} / \mathrm{ml}$ for the CRSwNP group, $71.3 \pm 16 \mathrm{ng} /$ $\mathrm{ml}$ for the CRSwONP group, and $61.9 \pm 11.6 \mathrm{ng} / \mathrm{ml}$ for the control group $(p<0.001)$. The Samter's triad group had a significantly higher calprotectin value than the nonSamter's triad group $(p=0.03)$. There was a significant correlation between the NOSE scores and calprotectin levels (rho $=0.734, p<0.001)$. Conclusion: Serum calprotectin values were correlated with the severity of symptoms in patients with CRS; thus, it seems to be a valuable pro-inflammatory biomarker for the diagnosis of the disease and determining its severity. Further studies with larger series are needed to evaluate the preoperative and postoperative serum calprotectin values in patients undergoing surgery.
\end{abstract}

Key words: chronic rhinosinusitis, nasal polyp, calprotectin

Received: 10 March, 2020; revised: 09 May, 2020; accepted: 18 August, 2020; available on-line: 31 August, 2020

छe-mail: doktorent@gmail.com

Abbreviations: CALP, Calprotectin; Cht, Chitotriosidase; CRS chronic rhinosinusitis; CRSwNP, chronic rhinosinusitis with polyps; CRSwoNP, chronic rhinosinusitis without polyps; ESS, endoscopic sinus surgery; ISSHL, idiopathic sudden sensorineural hearing loss ; NOSE, Nose Obstruction Symptom Evaluation; S.D., standard deviation; SPARC, serum secreted protein acidic and cysteine-rich

\section{INTRODUCTION}

Calprotectin is a heterodimer complex of S100A8 and S100A9 proteins that are members of the S100 protein family (Kato et al., 2017). It is a cytosolic protein complex of human neutrophils and also has bacteriostatic properties (Vogl et al., 2007). Calprotectin is expressed during myeloid differentiation, is abundant in neutrophil granulocytes and monocytes. Myeloid cells, which are developed in the bone marrow, migrate in large amounts into the blood and further into tissues in many diseases and conditions, like cystic fibrosis, rheumatoid arthritis and many inflammations and malignant diseases. Thus, elevated calprotectin levels in the serum can be used as a strong clinical marker indicating the presence of inflammation (Loser et al, 2010). Studies have shown that calprotectin has a strong pro-inflammatory effect (Dale et al., 1989; El-Rifai et al., 2002). In case of inflammation, increased calprotectin has also been reported in pathological tissue (nasal lavage fluid, exudates, autoimmune diseases, etc.) (Brahian et al., 2009; Tieu et al., 2010). It is also suggested that if a high concentration of calprotectin is present in the body fluid at local inflammatory sites, this might cause a delay in tissue repair and a deleterious effect on the inflamed tissue (Yui et al., 2003).

Chronic rhinosinusitis (CRS) with nasal polyps (CRSwNP) is a disease accompanied by chronic inflammatory conditions in the upper airways, which seriously impair the quality of life of the patient (Bachert et al., 2010). Various factors, such as viral and bacterial agents (Van Zele et al., 2004; Patou et al., 2008), epithelial barrier disorders, and tissue remodeling (Zhang et al., 2010; Van Bruaene et al., 2011; Van Crombruggen et al., 2013) play a role in the etiology of CRSwNP. However, the pathophysiology of CRSwNP has not yet been clearly elucidated (Van Crombruggen et al., 2011). The coexistence of nasal polyps, asthma and aspirin allergy is called Samter's triad and leads to more severe and persistent complaints related to nasal polyps (Kim et al., 2007). In a randomized, case-control study by Dutu and others (Dutu et al., 2018), the authors focused on the evaluation of serum chitotriosidase (Cht) and 25-hydroxyvitamin D3 (25-OH-D3) as potential biomarkers of CRS associated inflammation, and it was reported that serum Cht activity was significantly increased in CRS patients, compared to the controls, while 25-OH-D3 levels were significantly decreased in patients, versus controls. To the best of our knowledge, there is currently no test that provides information at the onset of complaints about the possible severity during the course of the disease.

There are only a limited number of studies on the role of calprotectin in the mechanism of upper airway inflammation (Van Crombruggen et al., 2016; Kuzucu et al., 2019). The current study aimed to measure the serum calprotectin levels in patients with sinonasal disease and determine the applicability of calprotectin as a potential molecular biomarker for CRS.

\section{MATERIALS AND METHODS}

This prospective, cross-sectional, historical cohort study was approved by the local ethics committee and carried out 
Table 1. Demographic features of patients

\begin{tabular}{lllll}
\hline Variables & CRSwNP Group (n:26) & CRSwoNP Group (n:24) & Control Group (n:27) & $p$ \\
\hline $\begin{array}{l}\text { Age (years) } \\
\text { (Mean } \pm \text { S.D.) }\end{array}$ & $43 \pm 17$ & $46 \pm 16$ & $40 \pm 14$ & $0.45^{*}$ \\
\hline Gender, $\mathrm{n}$ & & & & 14 \\
\hline Female & 12 & 11 & 13 & $0.88^{* *}$ \\
\hline Male & 14 & 13 & 8 & 19 \\
\hline $\begin{array}{c}\text { Smoking, } \mathrm{n} \\
\text { Yes }\end{array}$ & 10 & & & - \\
No & 16 & 16 & 0 \\
\hline $\begin{array}{c}\text { Samter's Triad, } \mathrm{n} \\
\text { Yes }\end{array}$ & 6 & 27 & - \\
No & 20 & 0 & 24 & \\
\hline
\end{tabular}

CRSwNP, chronic rhinosinusitis with nasal polyps; CRSwoNP, chronic rhinosinusitis without nasal polyps; S.D., standard deviation. *One-way analysis of variance. ${ }^{* *}$ Kruskal-Wallis analysis

in accordance with the ethical principles of the Helsinki Declaration. The study was conducted with volunteers in a single center between July 2018 and January 2019.

Volunteers were divided into three groups: The first group comprised patients diagnosed with CRS and found to have nasal polyps on endoscopic nasal examination (CRSwNP); the second group consisted of those diagnosed with chronic rhinosinusitis without nasal polyps (CRSwoNP) on endoscopic nasal examination; and the last group was formed by healthy controls. The demographic and clinical information was obtained from the participants, and their medical records, age, gender, smoking status, presence of asthma, aspirin-induced respiratory status, and Samter's triad were noted.

The patients in the CRSwNP group were also evaluated separately by further dividing them into sub-groups depending on the presence or absence of Samter's triad (nasal polyps, aspirin allergy, and asthma).

The Nose Obstruction Symptom Evaluation (NOSE) scale, consisting of five items that measure the effect of the disease on quality of life based on five points ( 0 to 4 ), was verbally administered to the participants. The results of the scale were multiplied by five; thus, the maximum NOSE score was 100.

Individuals under 18 or over 65 years of age, those with inverted papilloma, cystic fibrosis, sinonasal granulomatosis, any autoimmune disease, a history of acute or chronic infection or symptoms of infection, hypertension, angina pectoris, myocardial infarction, diabetes mellitus, metabolic syndrome, chronic obstructive pulmonary disease, amyloidosis, chronic renal failure, or cancer, those that had used oral steroids within the past month, and pregnant women were excluded from the study.

Laboratory Analysis. Before starting treatment, the serum calprotectin value was examined in venous blood collected in the morning after eight-hour fasting. The calprotectin measurement was performed using a Human CALP (calprotectin) ELISA kit on a Chemwell 2900 (Algen) analyzer. The results were reported in $\mathrm{ng} / \mathrm{mL}$. The intraassay and interassay coefficient variation $(\mathrm{CV} \%)$ values were found as 3.92 and 4.76, respectively. All samples were analyzed in duplicate, and the mean values were used for statistical analysis.

Statistical Analysis. The results were presented as mean \pm standard deviation (S.D.). We confirmed the normal distribution of the data using the Kolmogorov-Smirnov normality test $(p=0.2)$. To compare the mean ages of the groups, we used one-way analysis of variance, and to compare the gender (ordinal variable) distribution of the groups, we conducted the Kruskal-Wallis analysis. To assess the homogeneity of variances, we used the Levente test $(p=0.012)$.

The calprotectin levels of three groups were compared using the Welch analysis of variance. For advanced pairwise comparisons, Tamhane T2 was employed as a post- hoc test. Student's $t$-test was undertaken to compare the differences between the patients with and without Samter's triad and those between smokers and non-smokers. The association between the NOSE score (ordinal variable) and calprotectin levels was evaluated using the Spearman correlation test. We performed the statistical analysis using SPSS 16.0 software for Windows (SPSS, Inc., Chicago, IL), considering a $\mathrm{P}$ value of less than 0.05 as statistically significant.

\section{RESULTS}

There were a total of 77 participants, 40 males (52\%) and 37 females $(48 \%)$. The age of the participants ranged from 26 to 62 years. The mean age and gender distribution did not significantly differ between the three groups ( $p=0.45$ and $p=0.88$, respectively). The demographic features of the study sample are shown in Table 1.

The mean serum calprotectin value was $79.5 \pm 11.8$ $\mathrm{ng} / \mathrm{ml}$ for the CRSwNP group, $71.3 \pm 16 \mathrm{ng} / \mathrm{ml}$ for the CRSwoNP group, and $61.9 \pm 11.6 \mathrm{ng} / \mathrm{ml}$ for the control group. The Welch analysis of variance revealed that the mean calprotectin levels significantly differed between the groups $(p<0.001)$ (Table 2$)$. The post-hoc comparison tests showed that the mean calprotectin level of the CRSwNP group was significantly higher compared to the control group $(p<0.001)$, but did not significantly differ from that of the CRSwoNP group $(p=0.13)$. Additionally, the mean calprotectin level of the CRSwoNP group was higher than that of the control group, but this was not statistically significant $(p=0.06)$ (Table 2$)$.

Samter's triad was detected in six patients in the CRSwNP group. The mean calprotectin value was $88.5 \pm 10.1 \mathrm{ng} / \mathrm{ml}$ for the patients with Samter's triad and 76.8 $\pm 11.1 \mathrm{ng} / \mathrm{ml}$ for the remaining patients in the CRSwNP group, which indicated a statistically significant difference between these two subgroups $(p=0.03$ ) (Table 3).

There was no significant difference between the mean calprotectin levels of smokers and non-smokers $(p=0.4)$ (Table 4). 
Table 2. Comparison of the mean calprotectin levels between groups

\begin{tabular}{|c|c|c|c|c|}
\hline & $\begin{array}{l}\text { CRSwNP Group } 1 \text { (n:26) } \\
\text { Mean } \pm \text { S.D. }\end{array}$ & $\begin{array}{l}\text { CRSwoNP Group } 2 \text { (n:24) } \\
\text { Mean } \pm \text { S.D. }\end{array}$ & $\begin{array}{l}\text { Control }^{3}(\mathrm{n}: 27) \\
\text { Mean } \pm \text { S.D. }\end{array}$ & $p$ \\
\hline Calprotectin (ng/ml) & $79.5 \pm 11.8$ & $71.3 \pm 16$ & $61.9 \pm 11.6$ & $\begin{array}{l}0.001^{*} \\
1-2 p=0.13^{* *} \\
{ }^{2-3} p=0.06^{* *} \\
{ }^{1-3} p<0.001^{* *}\end{array}$ \\
\hline
\end{tabular}

CRSwNP, Chronic rhinosinusitis with nasal polyps; CRSwoNP, chronic rhinosinusitis without nasal polyps; S.D., standard deviation. *Welch analysis of variance, **Tamhane T2 post-hoc test

Table 3. Calprotectin levels in CRwNP patients with and without Samter's triad

\begin{tabular}{ll}
\hline & $\begin{array}{l}\text { Mean calprotectin levels } \\
(\mathrm{ng} / \mathrm{ml}) \pm \text { S.D. }\end{array}$ \\
\hline With Samter's Triad $(\mathrm{n}=6)$ & $88.5 \pm 10.1$ \\
\hline Without Samter's Triad $(\mathrm{n}=20)$ & $76.8 \pm 11.1$ \\
\hline$p$ & $0.03^{*}$ \\
\hline
\end{tabular}

CRSwNP, Chronic rhinosinusitis with nasal polyps; S.D., standard deviation; *Student's $t$-test
Table 4. Calprotectin levels of smoker and non-smoker patients with CRS

\begin{tabular}{ll}
\hline & $\begin{array}{l}\text { Mean calprotectin levels } \\
(\mathrm{ng} / \mathrm{ml}) \pm \text { S.D. }\end{array}$ \\
\hline Smokers $(\mathrm{n}=18)$ & $77.9 \pm 14.4$ \\
\hline Non-smokers $(\mathrm{n}=32)$ & $74.3 \pm 14.5$ \\
\hline$p$ & $0.40^{*}$ \\
\hline
\end{tabular}

CRS, Chronic rhinosinusitis; S.D., standard deviation; *Student's $t$-test

Table 5. Comparison of the mean NOSE scores between groups

\begin{tabular}{|c|c|c|c|c|}
\hline & $\begin{array}{l}\text { CRSwNP Group (n:26) } \\
\text { Mean } \pm \text { S.D. }\end{array}$ & $\begin{array}{l}\text { CRSwoNP Group (n:24) } \\
\text { Mean } \pm \text { S.D. }\end{array}$ & $\begin{array}{l}\text { Control (n:27) } \\
\text { Mean } \pm \text { S.D. }\end{array}$ & $p$ \\
\hline NOSE score & $75 \pm 9.8$ & $63.75 \pm 15.0$ & $32.77 \pm 6.8$ & $\begin{array}{l}<0.001^{*} \\
\text { Rho: } 0.734^{* *}\end{array}$ \\
\hline
\end{tabular}

CRSWNP, Chronic rhinosinusitis with nasal polyps; CRSwoNP, chronic rhinosinusitis without nasal polyps; S.D., standard deviation; *Welch analysis of variance; **Spearman correlation test

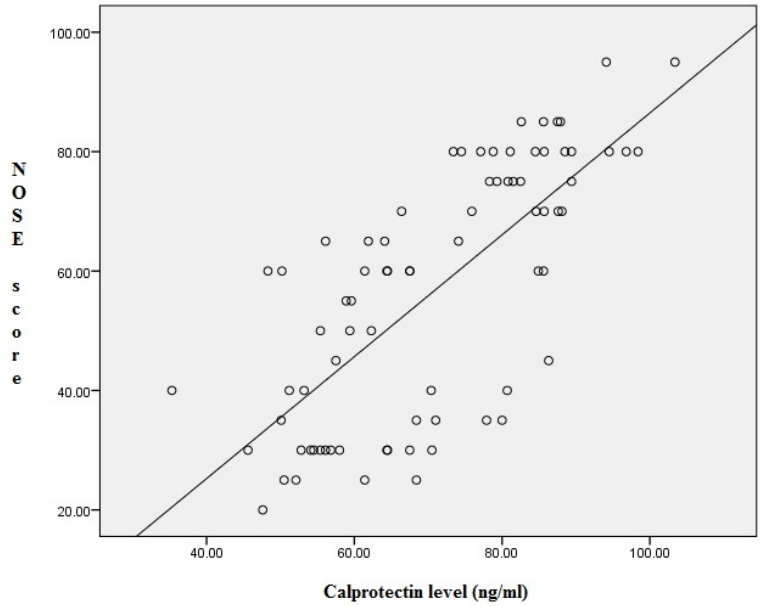

Figure 1. Scatter plot showing relationship between the NOSE scores and Calprotectin levels of the participants.

The many small circles represent the plotted values obtained for each of the variables while the line represents the best fit for the correlation between them.

The mean NOSE score was calculated as $75 \pm 9.8$, $63.75 \pm 15$ and $32.77 \pm 6.8$ in CRSwNP, CRSwoNP and control groups, respectively. Furthermore, a significant positive correlation was found between the NOSE scores and calprotectin levels of the participants (rho: 0.734, $p<0.001$ ) (Table 5; Fig. 1).

\section{DISCUSSION}

In recent years, a growing number of studies have been undertaken to investigate the relationship between the serum calprotectin value and inflammatory upper respiratory tract diseases. In a study conducted with 44 participants, the authors compared the serum calprotectin values of idiopathic sudden sensorineural hearing loss (ISSHL) cases with healthy participants. The serum calprotectin levels of patients with ISSHL were found to be higher than healthy individuals. The authors also noted that the serum calprotectin value of the patients who did not recover from the disease was significantly higher compared to those with partial or total recovery (Kuzucu et al., 2019). In another study, the serum calprotectin levels were examined in CRSwNP patients, and it was reported that calprotectin within the cells was transferred to the extracellular matrix due to inflammation; thus, it was elevated in the serum (Van Crombruggen et al., 2016). In the current study, we analyzed the serum calprotectin value in patients with CRSwNP and CRSwoNP and also compared the serum calprotectin values in CRSwNP patients with and without Samter's triad. Similar to the study by Crombruggen et al., we found that the serum calprotectin levels of the CRSwNP patients were higher than those of the CRSwoNP patients and healthy individuals, and additionally, the serum calprotectin was higher in CRSwNP patients with Samter's triad compared to those without this condition. We consider that this may be caused by the presence of an additional disease; i.e., asthma triggering inflammation and nasal polyp complaints being more severe in patients with Samter's triad.

In ultrastructural analysis, mast cell degranulation, which is responsible for high histamine levels in polyp fluids, has been shown to contribute to the formation of nasal polyps. Mast cells have mucosal and connective tissue types. In addition, basophils circulating in blood are transferred to tissues where they are transformed into mast cells (Naclerio et al., 2017). In a previous study that investigated the serum secreted protein acidic and cysteine-rich (SPARC) value in 26 patients 
with CRSwNP before and after endoscopic sinus surgery (ESS), the postoperative serum SPARC value was decreased by $33 \%$, but the authors noted that it was not possible to use SPARC to predict the course of the disease after ESS (Asmar et al., 2019). In another study, the authors sought an answer to the question of whether the serum periostin value could be used to determine the nasal polyp load in CRSwNP patients and found the level of this protein to be higher in CRSwNP patients compared to the CRSwoNP group. The researchers concluded that the serum periostin value could be used as a new molecular biomarker in the presence of nasal polyps (Maxfield et al., 2018). In the current study, we investigated the applicability of serum calprotectin as a biomarker in the presence of nasal polyps in patients with CRS. We also examined the serum calprotectin levels according to the presence/absence of Samter's triad. Our results showed that the serum calprotectin values were increased in the presence of Samter's triad compared to the CRSwNP patients without Samter's triad.

There are studies showing that the NOSE scale provides results consistent with computed tomography and physical examination findings in nasal surgery (Rhee et al., 2003; Kahveci et al., 2012). In a study that included 27 patients, the NOSE scale and septum deviation data on paranasal tomography were compared and found to be consistent (Rhee et al., 2003). Similarly, in another study, 345 patients were screened retrospectively, and the reliability of the NOSE score in revealing nasal obstruction was investigated. As a result, NOSE was shown to be a reliable instrument for the classification of nasal congestion complaints (Lipan et al., 2013). In light of these studies, we decided to standardize the patients' complaints of nasal congestion using the NOSE scale. We found a correlation between the NOSE scale scores and serum calprotectin values. Among the patients with CRS, nasal obstruction complaints were observed to be increased, particularly in those presenting with nasal polyps, which, in turn, elevated the serum calprotectin levels.

In this study, the serum calprotectin levels of the CRSwNP patients were significantly higher than those of the control group. At the same time, within the CRSwNP group, the serum calprotectin value was higher among the patients with Samter's triad compared to the remaining patients. In the light of these values, it can be stated that the serum calprotectin value is increased with the increasing severity of CRS. In addition, the serum calprotectin value is elevated in parallel to the increase in the NOSE scale score; i.e., it is higher in patients with the complaints of nasal congestion.

In this study, there are two issues to be addressed. First, the sample was relatively small to reach a widely accepted conclusion. A more extensive survey of cases would be beneficial. Second, the influence of serum calprotectin levels on the patient response to treatment or prognosis needs to be studied. In future work, we aim to investigate whether serum calprotectin values can be used as a prognostic factor for CRS.

\section{CONCLUSION}

In conclusion, we observed an increase in the serum calprotectin value in cases with CRS, and the severity of CRS symptoms correlated with the value of serum calprotectin. We recommend that a similar study should be undertaken with a larger case series to evaluate the pre- operative and postoperative serum calprotectin values in patients undergoing endoscopic sinus surgery.

\section{REFERENCES}

Asmar MH, Gaudreau A, Maniakas A, Mfuna Endam L, Desrosiers M (2019) An evaluation of SPARC protein as a serum biomarker of chronic rhinosinusitis. Otolaryngol Head Neck Surg 160: 158-164. https://doi.org/10.1177/0194599818801888

Bachert C, Zhang N, Holtappels G, De Lobel L, van Cauwenberge P, Liu S, Lin P, Bousquet J, Van Steen K (2010) Presence of IL-5 protein and $\mathrm{IgE}$ antibodies to staphylococcal enterotoxins in nasal polyps is associated with comorbid asthma. J Allergy Clin Immunol 126: 962-968. https://doi.org/10.1016/j.jaci.2010.07.007

Brahian H, Trovik J, Wik E, Stefansson IM, Akslen LA, Salvesen HB, Akslen LA, Salvesen HB, Staff AC (2009) Plasma calprotectin concentrations in woman with endometrial carcinoma. Gynecol Oncol 114: 491-495. https://doi.org/10.1016/j.ygyno.2009.06.008

Dale I, Brandtzaeg P (1989) Expression of the epithelial L1 antigen as an immunhistochemical marker of squamous cell carcinoma of the lung. Histopathology 14: 493-502. https://doi. org/10.1111/j.1365-2559.1989.tb02185.x

Duțu AG, Vlad D, Drugan C, Craciun AM, Drugan TC, Tăbăran FA, Albu S (2018) Biochemical markers of inflammatory syndrome in chronic rhinosinusitis. Rom Biotech Lett 25: 1456-1464. https://doi. org $/ 10.25083 / \mathrm{rbl} / 25.2 / 1456.1464$

El-Rifai W, Moskaluk CA, Abdrabbo MK, Harper J, Yoshida C, Riggins GJ, Frierson Jr HF, Powell SM (2002) Gastric cancers overexpress S100A calcium-binding proteins. Cancer Res 62: 6823-6826. PMID: 12460893

Kahveci OK, Miman MC, Yucel A, Yucedag F, Okur E, Altuntas A (2012) The efficiency of Nose Obstruction Symptom Evaluation (NOSE) scale on patients with nasal septal deviation. Auris Nasus Larynx 39: 275-279. https://doi.org/10.1016/i.anl.2011.08.006

Kato T, Kouzaki H, Matsumoto K, Hosoi J, Shimizu T (2017) The effect of calprotectin on TSLP and IL- 25 production from airway epithelial cells. Allergol Int 66: 281-289. https://doi.org/10.1016/j. alit.2016.06.011

Kim JE, Kountakis SE (2007) The prevalence of samter's triad in patients undergoing functional endoscopic sinus surgery. Ear, Nose Throat J 86: 396-399. https://doi.org/10.1177/014556130708600715

Kuzucu I, Candar T, Baklaci D, Guler I, Kum RO, Arslan H, et al (2019) A prognostic marker in idiopathic sudden sensorineural hearing loss: serum calprotectin. Clin Exp Otorbinolaryngol 13: 36-40. https://doi.org/10.21053/ceo.2019.00283

Lipan MJ, Most SP (2013) Development of a severity classification system for subjective nasal obstruction. JAMA 15: 358-361. https:// doi.org/10.1001/jamafacial.2013.344

Loser K, Vogl T, Voskort M, Lueken A, Kupas A, Nacken W, et al (2010) The Toll-like receptor 4 ligands Mrp8 and Mrp14 are crucial in the development of autoreactive CD8+ T cells. Nat Med 16: 713-717. https://doi.org/10.1038/nm.2150

Maxfield AZ, Landegger LD, Brook CD, Lehmann AE, Campbell AP, Bergmark RW, Stankovic KM, Metson R (2018) Periostin as a biomarker for nasal polyps in chronic rhinosinusitis. Otolaryngol Head Neck Surg 158: 181-186. https://doi.org/10.1177/0194599817737967

Naclerio RM, Baroody FM, Pinto JM (2017) Nasal polyps and biomarkers. J Allergy Clin Immunol 5: 1589-1590. https://doi.org/10.1016/j. jaip.2017.05.007

Patou J, Gevaert P, Van Zele T, Holtappels G, van Cauwenberge P, Bachert C (2008) Staphylococcus aureus enterotoxin B, protein A, and lipoteichoic acid stimulations in nasal polyps. I Allergy Clin Immunol 121: 110-115. https://doi.org/10.1016/j.jaci.2007.08.059

Rhee JS, Book DT, Burzynski M, Smith TL (2003) Quality of life assessment in nasal airway obstruction. Laryngoscope 113: 1118-1122. https://doi.org/10.1097/00005537-200307000-00004

Tieu DD, Peters AT, Carter RG, Suh L, Conley DB, Norton J, Grammer LC, Harris KE, Kato A, Kern RC, Schleimer RP (2010) Evidence for diminished levels of epithelial psoriasin and calprotectin in chronic rhinosinusitis. I Allergy Clin Immunol 125: 667-675. https://doi.org/10.1016/j.jaci.2009.11.045

Van Bruaene N, Bachert C (2011) Tissue remodeling in chronic rhinosinusitis. Curr Opin Allergy Clin Immunol 11: 8-11. https://doi. org/10.1097/ACI.0b013e32834233ef

Van Crombruggen K, Jacob F, Zhang N, Bachert C (2013) Damage-associated molecular patterns and their receptors in upper airway pathologies. Cell Mol Life Sci 70: 4307-4321. https://doi.org/10.1007/ s00018-013-1356-7

Van Crombruggen K, Zhang N, Gevaert P, Tomassen P, Bachert C (2011) Pathogenesis of chronic rhinosinusitis: inflammation. J Allergy Clin Immunol 128: 728-732. https://doi.org/10.1016/j. jaci.2011.07.049

Van Crombruggen K, Vogl T, Pérez-Novo C, Holtappels G, Bachert C (2016) Differential release and deposition of S100A8/A9 proteins in 
inflamed upper airway tissue. Eur Respir J 47: 264-274. https://doi. org/10.1183/13993003.00159-2015

Van Zele T, Gevaert P, Watelet JB, Claeys G, Holtappels G, van Cauwenberge P, Bachert C (2004) Staphylococcus aureus colonization and $\mathrm{IgE}$ antibody formation to enterotoxins is increased in nasal polyposis. J Allergy Clin Immunol 114: 981-983. https://doi.org/10.1016/j. jaci.2004.07.013

Vogl T, Tenbrock K, Ludwig S, Leukert N, Ehrhardt C, van Zoelen MA, Nacken W, Foell D, van der Poll T, Sorg C, Roth J (2007) Mrp8 and Mrp14 are endogenous activators of Toll-like receptor 4, promoting lethal, endotoxin-induced shock. Nat Med 13: 1042-1049. https://doi.org/10.1038/nm1638

Yui S, Nakatani Y, Mikami M (2003) Calprotectin (S100A8/S100A9), an inflammatory protein complex from neutrophils with a broad apoptosis-inducing activity. Biol Pharm Bull 26: 753-760. https://doi. org $/ 10.1248 / \mathrm{bpb} .26 .753$

Zhang N, Liu S, Lin P, Li X, van Bruaene N, Zhang J, van Zele T, Bachert C (2010) Remodeling and inflammation in Chinese versus white patients with chronic rhinosinusitis. I Allergy Clin Immunol 125: 507-508. https://doi.org/10.1016/j.jaci.2009.10.015 